
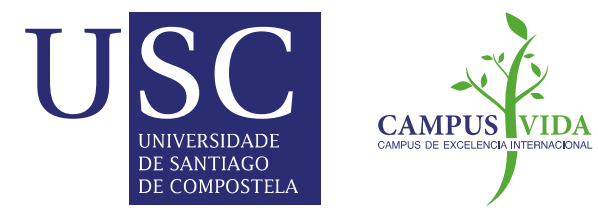

\title{
A metabolic model for targeted volatile fatty acids production by cofermentation of carbohydrates and proteins
}

Alberte Regueira, Riccardo Bevilacqua, Juan Manuel Lema, Marta Carballa, Miguel Mauricio-Iglesias

Bioresource Technology, Volume 298, February 2020, 122535.

Doi: 10.1016/j.biortech.2019.122535

\section{Supporting Information}




\title{
A metabolic model for targeted volatile fatty acids production by cofermentation of carbohydrates and proteins
}

\author{
A. Regueira*, Riccardo Bevilacqua, J. M. Lema, M. Carballa, M. Mauricio-Iglesias. \\ CRETUS Institute, Department of Chemical Engineering, Universidade de Santiago de \\ Compostela, 15782 Santiago de Compostela, Spain \\ *Corresponding author (e-mail: alberte.regueira@usc.es)
}

E-supplementary data 
Table S1. AA spectrum of gelatine used in the simulations (molar basis) and molecular weight of a C-mol of that protein.

\begin{tabular}{|c|c|}
\hline Arg & $4.7 \%$ \\
\hline Ala & $2.7 \%$ \\
\hline Asp & $6.3 \%$ \\
\hline Lys & $3.3 \%$ \\
\hline Glu & $5.0 \%$ \\
\hline Ser & $5.3 \%$ \\
\hline Thr & $11.0 \%$ \\
\hline Cys & $8.0 \%$ \\
\hline Gly & $11.6 \%$ \\
\hline Pro & $5.6 \%$ \\
\hline Val & $6.0 \%$ \\
\hline Ile & $3.3 \%$ \\
\hline Leu & $4.0 \%$ \\
\hline Met & $3.0 \%$ \\
\hline Gln & $9.6 \%$ \\
\hline Asn & $6.3 \%$ \\
\hline His & $4.3 \%$ \\
\hline MW (g/C-mol) & 29.0 \\
\hline
\end{tabular}


Table S2. Mass balances for the different compartments of the reactor. $S_{i}$ is the intracellular concentration, $R_{i}$ and $R_{T, i}$ are, respectively, the reaction rate and intra-extra cellular transport rate, $S_{k}$ is the extracellular concentration, $D_{l i q}$ is the liquid dilution rate, $S_{K, i n}$ is the concentration on the inlet, $S_{X}$ is the biomass concentration, $R_{\text {ana }}$ is the anabolism rate, $R_{\text {decay }}$ is the decay rate, $G_{m}$ is the concentration, $D_{g a s}$ is the gas space dilution rate and $R_{T, m}$ is liquidgas transport rate.

\begin{tabular}{|c|c|c|}
\hline Compartment & Equation & Units \\
\hline Intracellular compounds & $\frac{d S_{i}}{d t}=R_{i}+R_{T, i}$ & $\mathrm{~mol} \mathrm{~L}_{\mathrm{x}}^{-1} \mathrm{~h}^{-1}$ \\
\hline Extracellular compounds & $\frac{d S_{k}}{d t}=D_{l i q} \cdot\left(S_{K, \text { in }}-S_{k}\right)+R_{T, k}$ & $\mathrm{~mol} \mathrm{~L}_{\mathrm{liq}}^{-1} \mathrm{~h}^{-1}$ \\
\hline Biomass & $\frac{d S_{X}}{d t}=-D_{\text {liq }} \cdot S_{X}+R_{\text {ana }}-R_{\text {decay }}$ & $\mathrm{mol} \mathrm{L}_{\mathrm{r}}^{-1} \mathrm{~h}^{-1}$ \\
\hline Gas compounds & $\frac{d G_{m}}{d t}=-D_{g a s} \cdot G_{m}+R_{T, m}$ & $\mathrm{~mol} \mathrm{~L}_{\mathrm{gas}}^{-1} \mathrm{~h}^{-1}$ \\
\hline
\end{tabular}




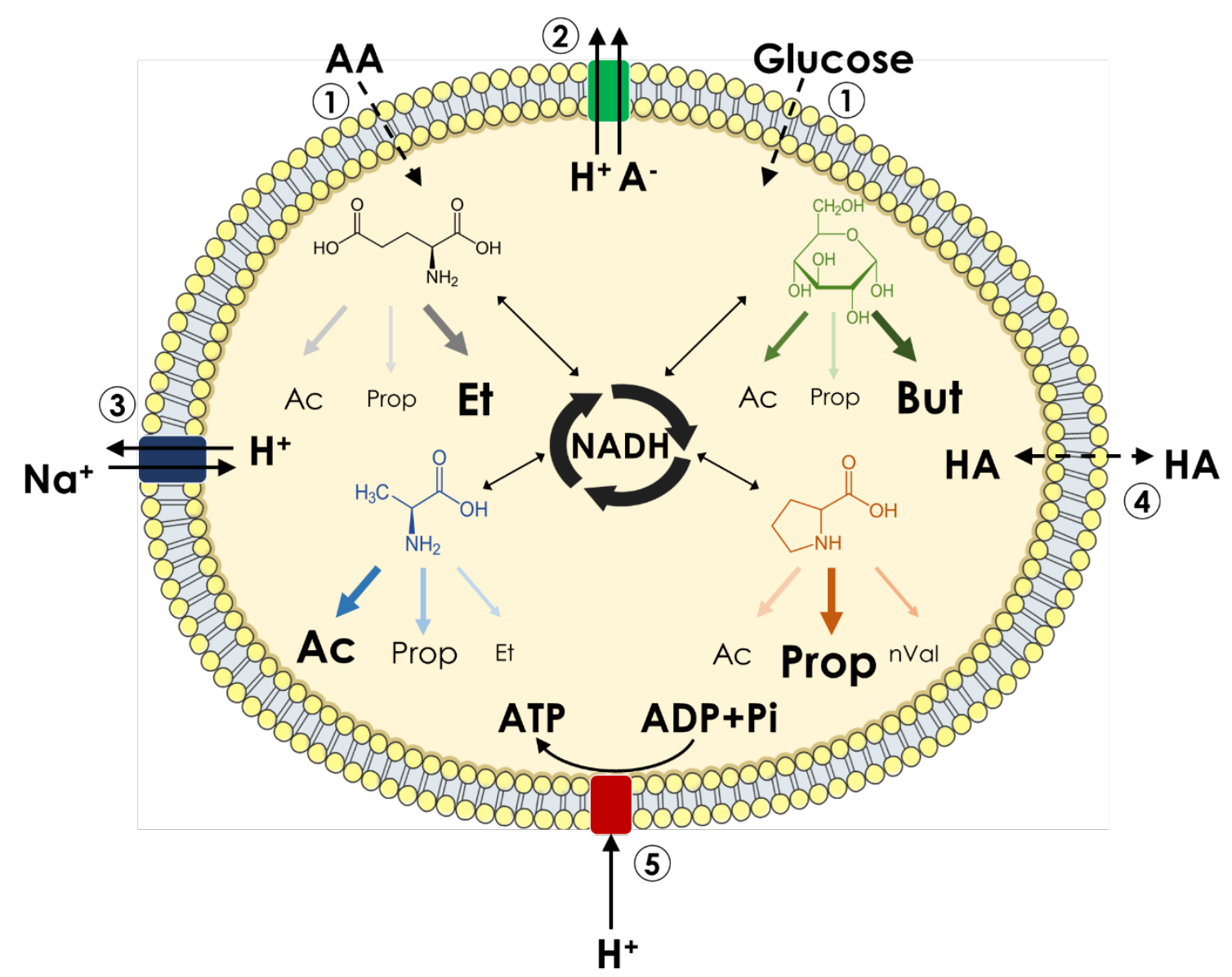

Fig. S1. Scheme of the processes considered in the model. 1: Passive transport of substrates is considered only to happen inwards the cell. 2: VFA active transport in a symport with protons. 3: Antiport transport of sodium and protons to regulate internal $\mathrm{pH}$. 4: Passive transport of VFA is considered to happen in both directions. 5: Energy is stored in form of ATP in proton translocation processes (ATP synthase). The catabolism of the different substrates is determined in the optimisation part of the model. The substrates interact with each other through the NADH conservation as its production and consumption must be balanced at all times. 


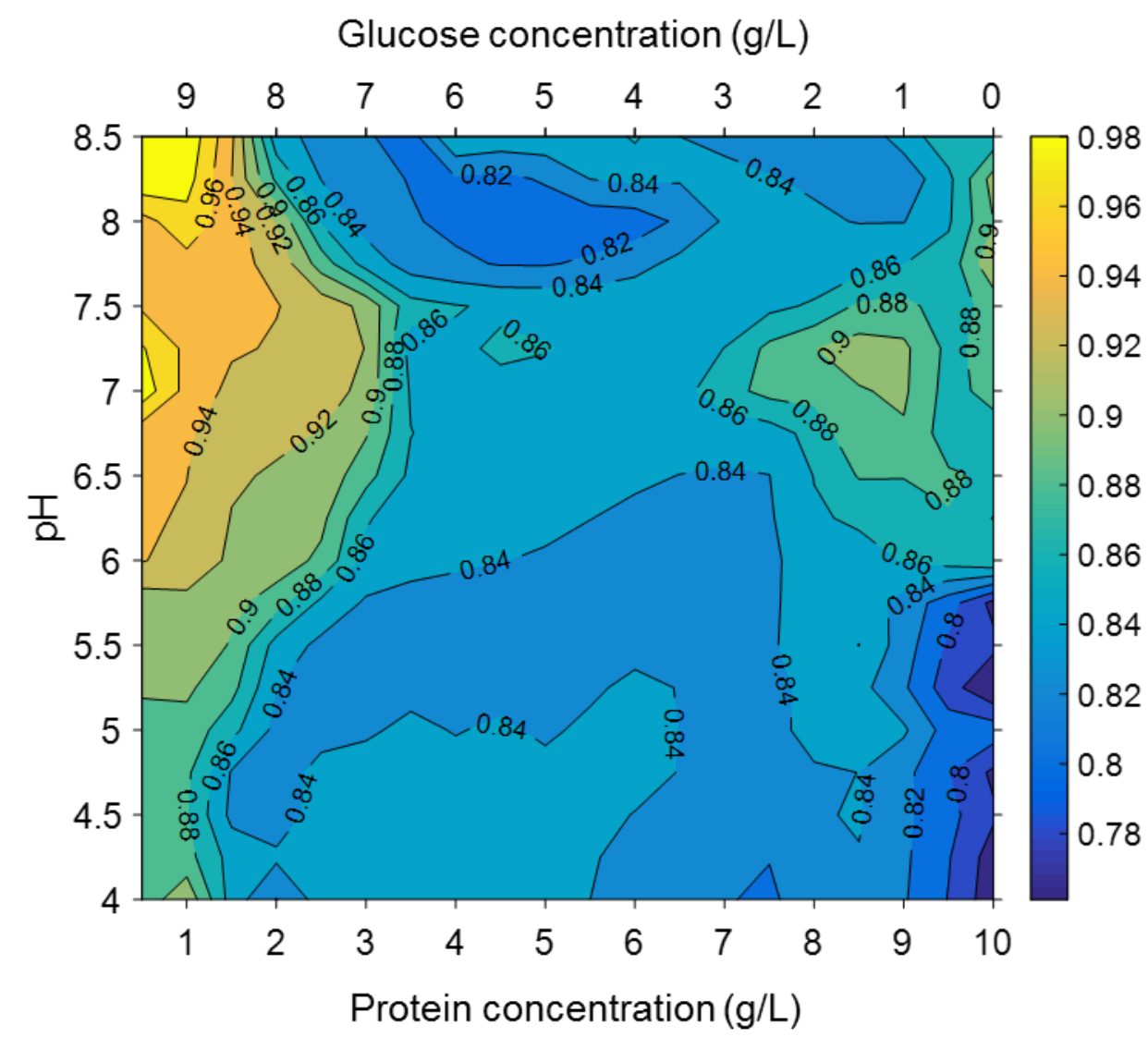

Fig. S2. Predicted protein conversion (g consumed/g feeding) at different $\mathrm{pH}$ values (vertical axis) and at different glucose and gelatine concentration in the feeding (horizontal axis). 


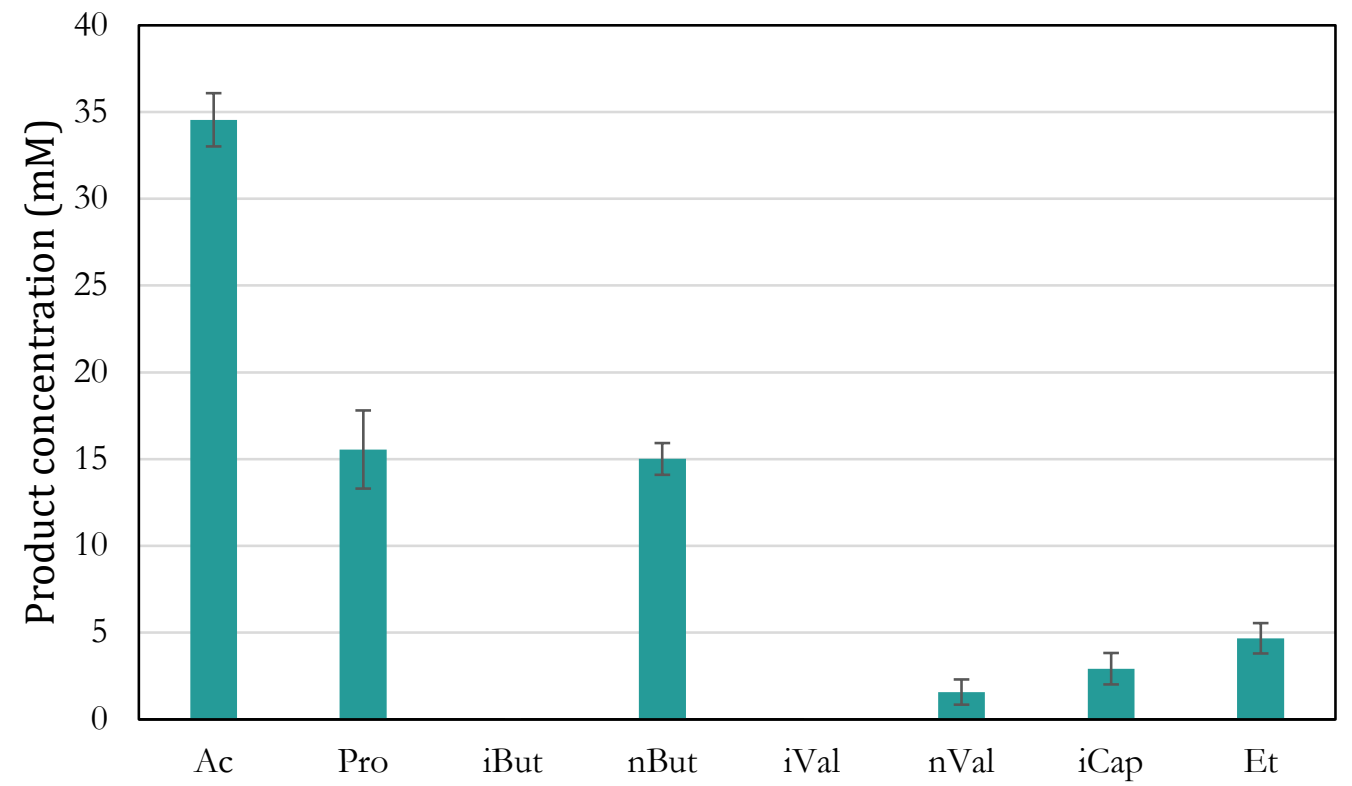

Fig. S3. Product variability due to different AA profiles. Model simulations at $5 \mathrm{~g} / \mathrm{L}$ of glucose and gelatine and at $\mathrm{pH} 7$ for 9 different gelatine AA profiles. 